\title{
One more interdisciplinary challenge: Incorporating Renewable Energy Teaching and Research at the Postgraduate Programme in Environment and Development of the Federal University of Paraná, Brazil
}

\author{
S. M. Andersen ${ }^{1}$, M. V. Lange ${ }^{2}$ and J. C. Pasqual ${ }^{1}$ \\ ${ }^{1}$ Professor at the Environment and Development Postgraduate Programme, in the Federal University of Paraná \\ Sector of Agricultural Sciences - Rua dos Funcionários 1540, Juveve, Curitiba, Parana, Brazil, CEP: 80035-050 \\ sigridandersen56@gmail.com \\ ${ }^{2}$ Doctoral student at the Environment and Development Postgraduate Programme, in the Federal University of Paraná \\ Sector of Agricultural Sciences - Rua dos Funcionários 1540, Juveve, Curitiba, Parana, Brazil, CEP: 80035-050 \\ marcelavlange@gmail.com
}

${ }^{3}$ Doctoral student at the Master's and Doctoral Programme in Urban Management, Pontifical Catholic University of Paraná, Curitiba, Paraná, 80215-901, International Center of Renewable Energies - Biogas and International Centre of Hydroinformatics, Foz do Iguaçu, Paraná, Brazil

Brazil E-mail: janaina@maxc.com.br

\begin{abstract}
This paper discusses the context and challenges of incorporating a new teaching and research nucleus on Renewable Energy in an interdisciplinary postgraduate programme based in the frontier between environmental and social sciences at the Federal University of Paraná, Brazil. The creation of the nucleus was boosted by a partnership with Itaipu Binational and aims to address the complex relationship among Energy, Environment and Development in a context of global environmental crisis. It gives rise to the beginning of a new phase of the programme with particular academic challenges and opportunities.
\end{abstract}

\section{Key words}

Teaching and Research, Renewable Energy, Interdisciplinarity, Posgraduate Programme.

\section{Introduction}

The Postgraduate Programme in Environment and Development at the Federal University of Paraná (PPGMADE) was created in 1993 and has the overall aim to produce knowledge with a level of excellence on the huge issue of Development and Environment, analyzing the society-nature relations from an interdisciplinary and critic frame that contributes to build an economically sustainable, environmentally responsible and socially just society. The programme provides theoretical, methodological and epistemological elements for interdisciplinary dialogue, organizing each new class around collective research programs.

Course target audience are people interested and/or involved in current environmental issues from various disciplinary backgrounds. Most of them are Brazilians and a small percentage of professionals from South American countries. Historically, the programme has contributed significantly to train teachers of higher education institutions and other levels of education, employees and experts from private companies and seniors of public institutions as well as members of non-governmental organizations, social movements, and other civil society organizations.

PPGMADE aims at graduating professionals with an interdisciplinary view of the environmental issue in order to understand the society-nature relation by integrating social, biological and natural sciences. These professionals are able to develop a critical understanding of development models that generate social injustice and environmental unsustainability, and are capable of generating knowledge, creatively and systematically, from various environmental themes. They can also contribute - while professionals and citizens - to propose just and sustainable alternatives in different situations, debates and conflicts that constitute the "EnvironmentDevelopment" issue in contemporary society.

In 2012, a partnership with Itaipu Binational allowed the construction of a teaching and research nucleus in Energy, Environment and Development, in order to address the complex relationship among these three themes in a context of global environmental crisis. This paper exposes the context, challenges and opportunities in the implementation of this new entity in PPGMADE.

\section{Interdisciplinarity in the environmental studies}


Interdisciplinarity emerges from the transition to a new scientific approach in which the subjects no longer remain closed in their particular objects, but open to new investigative adventures for the construction and exchange of knowledge [1]. Interdisciplinarity is a way to deal with complex, hybrid objects, which are at the frontiers of knowledge and cannot be adequately understood in isolation [1], [2].

Each discipline contributes in its own way with the object of study, according to the theoretical and methodological alignment in a dialogic and collaborative way [1], [2]. There is no intention in eliminating the disciplines, but, from the interdisciplinary dialogue, each of them can constantly reinvent its procedures and means of knowledge production[2].

Interdisciplinarity seeks to "restore the interdependencies and interrelationships between processes of different materiality and rationality orders" (p. 319, free translation), without subjugating "non scientific" knowledge, which is commonly marginalized because it does not comply with the paradigmatic standards of modern science, even being determinant for the processes studied by science[3]. Interdisciplinarity can also be understood as a characteristic methodological procedure of a mature phase of sciences that allows us to redirect their potential application to the social demand for knowledge[3].

The basis of interdisciplinary knowledge implies an epistemological break for the foundation of a new science or a new field of knowledge[3]. Interdisciplinarity not only entails the integration of different disciplines, but brings into question the rationality that generates them and the construction of a new rationality, i.e., the founding or refunding of knowledge objects in a transforming perspective of current knowledge paradigms, opening space to the hybridization of science, technology and popular knowledge.

The new rationality in which interdisciplinarity emerges also includes other features that can be drawn from the opinions disseminated by the academic and scientific community, such as (a) the link between cultural and political feelings in the production of rational knowledge by the scientist, (b) the recognition of alternative, technological, valuated and cultural knowledge, among others, (c) the recognition of power asymmetries in the global production of science, and (d) the rescue of ethical assessment on the production and use of scientific knowledge[1].

In the environment field - a multicentric and complex notion - the concerns that afflict humanity lead to a need for studies that consider the interaction between human practices and natural systems' dynamics, i.e. the relationship between society and environment [4], [5]. According to the authors, this area is given by an interdisciplinarity that occurs between disciplines of maximum distance, including the ones from materiality and immateriality. The environmental issue has a hybrid nature, requiring the crossing of different scientific looks on empirical realities, which is done through teamwork with various disciplines working in a non-hierarchical way around a common goal, the study of socioenvironmental complex objects[4].

\section{The emergence of the Postgraduate Programme in Environment and Development at the Federal University of Parana}

Interdisciplinarity came in the wake of questioning about epistemological implications of scientific knowledge, its social function, and its role in the academic and scientific research that crossed the twentieth century. Especially from the 1970s and 1980s, authors such as Morin and Leff began to question certain hegemonic ideas of science, its positivist tradition and the crisis that stems from its application in the field of societies. In universities and other institutions, space was opened for criticism of the use of science and the creation of alternatives for knowledge production[4].

Meanwhile, discussions about the global environmental crisis were increasing around the world, since first awareness in the late 1960s. In 1987, from the growing recognition of the environmental problem, the proposed sustainable development forged by Brundtland Report was accepted. In that decade, UFPR participated in the National Seminars on University and Environment.

In 1992, the UN Conference on Environment and Development (Rio-92) was held in Rio de Janeiro (Brazil). The mobilization around this event created an intense climate debate, as well as a search for ways of acting in this issue. In academia, it reflected on the search for ways of thinking the environmental issues through their inherent seriousness and complexity, trying to fulfil the insufficiency of the traditional disciplines.

Inspired by the environmental wave, the growing understanding of its complexity and the need for interdisciplinarity, a collective of local professors and professors of French universities as Paris VII, Paris X, Paris La Villette and Bordeaux II started a movement for creating an eminently interdisciplinary programme [4].

It was in this context that PPGMADE was created, in 1993. It was born under the auspices of the UNESCO (United Nations Educational, Scientific and Cultural Organization) Chair for Sustainable Development.

The interdisciplinary procedures adopted by the programme have their origins in studies started in the 1960s, especially in France, which sought to answer questions about the management and development of areas based on coordination between socioeconomic development and environmental protection [4].

The programme was organized with disciplines of life, nature and society sciences and cross-cutting issues. The integration was accomplished through modules instead of the traditional disciplines[4]. 
For seventeen years, the programme had worked only as a Doctoral degree. This was due to understand that the process of interdisciplinary training requires students who already have experience in their fields for the effective practice of collective research. In 2009, within the framework of REUNI I (Restructuring and Expansion of Federal Universities), a federal programme that encouraged the creation of new university courses, the Master degree has been created, starting in the first semester of 2010. By 2014, a total of 172 doctoral students, and a total of 48 master students joined the programme.

From 1999, the Programme has had four lines of research: (1) Environmental epistemology; (2) Ruralities, Environment, and Society; (3) Urbanization, City and Urban Environment; and (4) Uses and Conflicts of Coastal Environments.

Environmental epistemology analyzes and discusses philosophical and theoretic-methodological aspects on the social production of knowledge (scientific and nonscientific, from the environmental epistemology perspective); qualitative and quantitative aspects of development (ethics and environmental justice); conflicts, actors, subjects, eco-formation (rationality and subjectivity); and governance, social, and environmental impact of projects.

Ruralities, Environment and Society studies actors, subjects, rationalities, and conflicts in experiences, practices and areas of resistance in the rural areas. It also aims building alternatives for rural and agro-food system: solidarity economy networks, agro-ecological organization and production, construction of new market relations, consumption of healthy food, reframing of cooperation, movements and struggles for social and environmental rights, innovative public policies for rural or territorial development.

Urbanization, City and Urban Environment addresses urbanization and environment; global environmental change and cities; contemporary urban environmental problems; social and environmental risks, vulnerabilities and resilience in Brazilian cities; metropolisation and urban peripheralization; socio-spatial dynamics and complexity of urban environmental problems; and the relationship between society and nature and environmental conflicts in the Metropolitan Region of Curitiba.

Uses and conflicts of coastal environments analyses the forms of appropriation and use of natural resources in coastal regions and the issues and environmental conflicts arising within the framework of global changes and alternative proposals for management and development.

\section{The incorporation of the Energy, Environment, and Development research nucleus}

In 2003, PPGMADE was contacted by the International Centre for Hydroinformatics (CIH), a binational centre, resulting from a partnership between ITAIPU Binational and the International Hydrological Programme of UNESCO. CIH applies hydroinformatics to water management, and it is a UNESCO Category 2 Centre. When aware of the UNESCO Chair for Sustainable Development owned by PPGMADE, CIH started a movement based on the intention of adding forces of two organizations sealed by UNESCO on two common topics of interest: sustainable development and the water-energy nexus.

$\mathrm{CIH}$ is located in Itaipu Binational, one of the biggest hydroelectric power plants in the world implemented in the international Paraná River which borders Paraguay. The Center resulted from a sequence of events after the change in the company mission that occurred in 2003, which incorporated social and environmental responsibility and commitment to sustainable development, especially the creation of the Itaipu Technological Park (PTI). PTI is a scientific and technological centre, based in Brazil and Paraguay, focused on regional development and also the modernization of the hydroelectric plant - and the release of the "Cultivating Good Water" Programme - an extensive movement involving local actors in the pursuit of sustainable development in the Paraná 3 River Basin, area of direct influence of the dam, whose impacts could not only harm the hydroelectric power generation and its lifetime, but also the communities around them. These events derived the identification of the need for adequate information management to enable decision-making and planning in the river basin management, encouraging in 2006 the establishment of CIH, as part of PTI.

In 2008, the Observatory of Renewable Energy for Latin America and the Caribbean was also created in partnership with Itaipu Binational, which would later give birth to the International Centre of Renewable Energy - Biogas (CIBiogás). CIBiogás is a scientific, technological and innovation non-profit organization, formed by seventeen institutions that develop and/or support renewable energy projects. It aims to promote the sustainable development of the biogas chain and other renewables.

CIBiogás was also created as a response from Itaipu to a need that is urgent today: replacing fossil fuels by clean and renewable energy sources. The centre seeks to promote energy efficiency in the region through the use of alternative generating sources, such as solar, wind, biomass, and hydro.

Being contacted by $\mathrm{CIH}$ and aware of the last developments towards the renewable energy transition put into place by Itaipu, PPGMADE glimpsed the possibility of putting into operation a research nucleus on Renewable Energy covering the issue of technology and its relationship with the society and the environment.

One of the most commented environmental challenges being faced by humanity is the energy generation and consumption. Humans and societies have become a global geophysical force at the current epoch, named 
Anthropocene, especially because of the energy choices done. The epoch began around 1800 with the onset of industrialization, whose central feature was the huge expansion in the use of fossil fuels, leading to elevation of the carbon dioxide concentration in the atmosphere of a pre-industrial value of $270-275 \mathrm{ppm}$ to about $310 \mathrm{ppm}$ in 1950. Since then human enterprise experienced a remarkable explosion, the great acceleration - which can be seen in the exponential growth of various human activities with significant consequences for the functioning of the Earth System. The concentration of atmospheric $\mathrm{CO} 2$ has increased from 310 to $380 \mathrm{ppm}$ since 1950, with about half of the total increase since pre-industrial era occurred in the last 30 years[6].

The scientific consensus that the Earth's climate is being affected by human activities is clearly expressed in the reports of the Intergovernmental Panel on Climate Change (IPCC), as well as documents published by other relevant organizations[7]. The latest report of the IPCC Working Group I, assessed the latest scientific knowledge on climate change and concluded that it is clear that climate change is occurring and that there is at least $95 \%$ sure human activities are the main cause[8].

Renewable energies play a fundamental role in the transition to a sustainable development. Although not free from causing numerous changes in the environment, as all human activities, renewable energy appears today as the best (or as the least bad) choices for a sustainable future for the humanity.

Itaipu Binational, CIH, CIBiogás and their partners have a consolidated trajectory on promoting renewable energy, thus they become interesting allies in the pursuit of energy solutions that favour sustainable development. The Energy, Environment, and Development research nucleus was then formed, in order to strength research in this area and also form professionals with academic and practical view of energy, environment, and development issues.

The research nucleus aims to analyse and discuss the energy challenges faced in environmental global crisis; the resources and uses of energy; the Brazilian energy model and its technical, economic, and environmental implications; environmental and energy justice; the role of renewable energy in sustainable development; appropriate technologies, territorial planning and public policies; resilience of energy and water systems; and the waterenergy nexus: constraints and possibilities.

\section{Conclusion}

With the incorporation of the theme Renewable Energy in the Postgraduate Programme on Environment and Development (PPGMADE) at the Federal University of Paraná, Brazil, some challenges and opportunities have shown evident. The most important seems to be related to the methodological and epistemological perspectives. The epistemological aspect embodies the creation and dissemination of a new kind of knowledge, which looks at the energy issue from an interdisciplinary angle. There is much to be constructed.
From a methodological aspect, the challenge is very similar to those already faced by PPGMADE when attempting to implement interdisciplinarity in its academic practice. Now, it relates to the difficulties in finding methodological approaches to enable the study of the interdependencies, interrelationships and nexus between energy and development issues, taking into account not only environmental but also social considerations within the frame of sustainable development.

The incorporation of new professionals to form a team of leading researchers in the recently created renewable energy nucleus is another challenge. It is necessary to identify researches and professors coming from the technological field whose main characteristic should be openness, receptiveness, understanding, flexibility and amplitude of thinking to study energy in a wider and interdisciplinary context taking into account complex social, environmental and biological contexts.

Another challenge that has to be faced is the promotion of fluid dialogue and cooperation between three different institutions - CIH, Itaipu Binational and PPGMADEwho develop different paces, logics and rationalities. The administration of Itaipu, the largest hydroelectric enterprise of the Brazilian electric sector involves strategic planning, rigid and prescriptive roles and a system of internal organization to meet goals and pursue efficient results. This contrasts with the different timing of the academic thinking and production.

Another opportunity that emerges with this cooperation is the possibility of developing extension programmes, an aspect of education which is still little explored in the Postgraduate Programme and at the Federal University of Paraná as a whole. Extension shortens the distance between the academic world and the communities that surround it, being fundamental to the formation of academic citizens, promoting social inclusion and public awareness and proposals for sustainable development.

The empirical work being developed in projects by $\mathrm{CIH}$ and Itaipu Binational in the Paraná river basin also consists in a fertile laboratory for professors and students for practical experiments and to provide critical analyses to project evaluation, improvements and innovations.

\section{References}

[1] D. FLORIANI, "Ciências em trânsito, objetos complexos: práticas e discursos socioambientais," Ambient. Soc., vol. 9, no. 1, pp. 65-80, 2006.

[2] C. RAYNAUT, "Interdisciplinaridade: mundo contemporâneo, complexidade e desafios à produção e à aplicação de conhecimentos," in Interdisciplinaridade em ciência, tecnologia e inovação, A. Philippi Junior and A. J. Silva Neto, Eds. São Paulo: Manole, 2011, pp. 69-142.

[3] E. LEFF, "Complexidade, interdisciplinaridade e saber ambiental," Olhar Profr., vol. 14, no. 2, pp. 309-335, 2011.

[4] D. Floriani, A. Brandenburg, A. D. D. Ferreira, C. Teixeira, F. de A. Mendonça, J. E. de S. Lima, J. M. 
Andriguetto Filho, M. do R. Knechtel, and P. da C.

Lana, "Construção interdisciplinar do Programa de Pós-

Graduação em Meio Ambiente e Desenvolvimento da

UFPR," in Interdisciplinaridade em ciência, tecnologia e inovação, A. Philippi Junior and A. J. Silva Neto, Eds.

São Paulo: Manole, 2011, pp. 342-378.

[5] C. RAYNAUT and M. ZANONI, "Reflexões sobre princípios de uma prática interdisciplinar na pesquisa e no ensino superior," in Interdisciplinaridade em ciência, tecnologia e inovação, A. Philippi Junior and A. J. Silva Neto, Eds. São Paulo: Manole, 2011, pp. 143-208.

[6] W. Steffen, J. Crutzen, and J. R. McNeill, "The Anthropocene: are humans now overwhelming the great forces of Nature?," Ambio, vol. 36, no. 8, pp. 614-621, 2007.

[7] N. ORESKES, "The Scientific Consensus on Climate Change," Sci. Essays Sci. Soc., vol. 306, no. 5702, pp. 1686-1686, 2004.

[8] IPCC, "Summary for Policymakers: Climate Change 2013: The Physical Science Basis. Working group I contribution to the Fifith Assessment Report of The Intergovernmental Panel on Climate Change," Cambridge, United Kingdom and New York, Usa, 2013. 